\title{
Effect of coal mining on soil physico-chemical properties of Nokrek Biosphere Reserve of Meghalaya, northeastern India
}

\author{
Vanlalhruaii Ralte \\ Department of Botany, Pachhunga University College, Aizawl 7960oI, India
}

Mining causes massive damage to landscape and biological components of an ecosystem. Due to extensive and unmanaged coal mining in the southern part of Nokrek Biosphere Reserve of Meghalaya, the area has been turned into degraded land since nutrient deficient sandy spoils are hostile for the growth and regeneration of plant communities. Soil is sandy to sandy loam and red, brown to dark brown in colour. The physico-chemical properties of the soil were greatly affected due to coal mining. There is an increased acidity i.e. from 6.00 in the undisturbed forest (control site) to 3.50 in the coal mine spoil since abandoned mine spoil discharge acidic water that are enriched with iron and other metals and metalloids. Apart from this, soil nutrients are greatly depleted. The core zone soils are rich in organic matter and nutrients whereas coalmine spoils show sign of degradation especially in the nutrient content.

Key words: Coal mine spoil; soil properties; Nokrek Biosphere Reserve.
Received 13 October 2017 Accepted 06 November 2017

*For correspondence $\bowtie$ : apuii_r@yahoo.com

\section{Introduction}

Surface mining of coal causes enormous damage to the flora, fauna, disrupts local hydrological cycle and alters characteristics of soil system due to destruction of the vegetal cover. On a global scale about 20 percent deforestation in developing countries may be attributable to mining. ${ }^{1}$ Low concentrations of $\mathrm{N}$ and $\mathrm{P}$ were observed by Maharana and Patelin Basundhara open cast coal mine dump soils. ${ }^{2}$ Specific soilrelated constraints to mine soil reclamation are low $\mathrm{pH}$, soil erosion, elemental toxicity (e.g. Al, $\mathrm{Mn}$, etc.) and non-availability of $\mathrm{N}, \mathrm{P}$ and $\mathrm{K}$ in the spoil. ${ }^{3}$ Nutrient-deficient sandy mine spoils are generally hostile to plant growth and revegetation. Reclamation strategies, other than natu- ral colonization, are very tardy process.

A proper understanding of the impact of mining on the vegetation, biodiversity and soil is a pre-requisite for the effective management of the biosphere reserve. The main objective of the present research thus was to study the impact of mining on the physico-chemical properties of soils of the buffer zone of the biosphere reserve.

\section{Materials and Methods}

\section{Study site}

Nokrek Biosphere Reserve is spread over an area of 820 sq. $\mathrm{km}$ covering parts of East Garo Hills, West Garo Hills and South Garo Hills districts of Meghalaya. It lies between $90^{\circ} 13^{\prime} \mathrm{E}$ and 


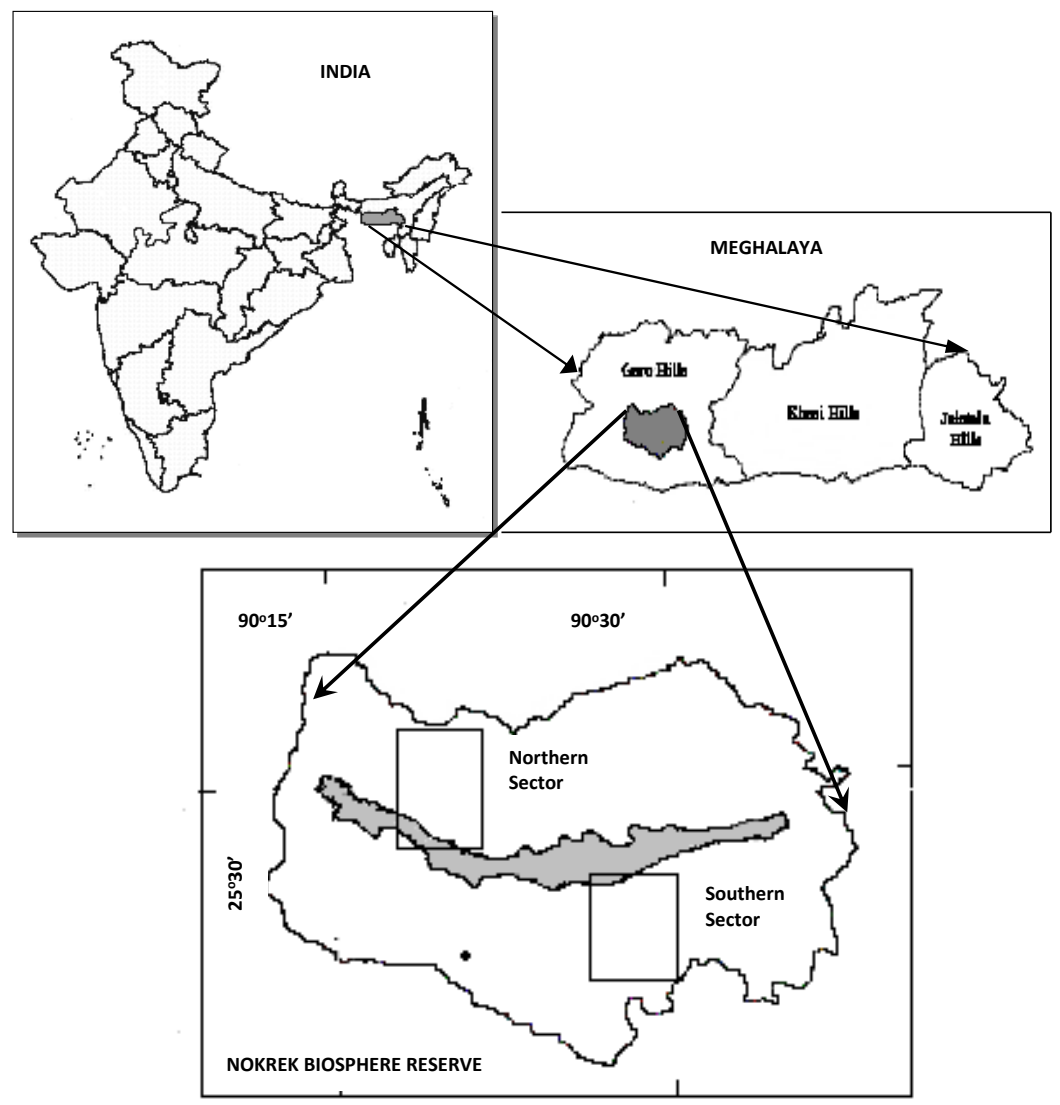

Figure 1 | Map showing the location of study sites in the Nokrek Biosphere Reserve, Meghalaya.

90³5’ E longitudes (Fig. 1). The NBR is situated on entirely hilly terrain of Tura ranges of mountain system ranging from $200 \mathrm{~m}$ to $1412 \mathrm{~m}$ altitude. The highest peak of this ridge called Nokrek Peak (1412 $\mathrm{m}$ a.s.l.) lies within the core zone of the Nokrek BR. The core zone, which is also designated as Nokrek National Park, comprises of $47.48 \mathrm{sq}$. km area of the ridge of Nokrek Hills, spread in east-west direction. The core zone supporting the virgin vegetation of the area is also the catchment area of the major rivers of the Garo Hills, namely Simsang, Dedari, Dareng and Ganol, which originate from the Nokrek BR. The buffer zone of the Nokrek BR has an area of $772.52 \mathrm{sq} . \mathrm{km}$.

In entire Garo Hills districts the total reserve of coal has been estimated to be 39,000 million tonnes, and West Derenggre area comprises more than $35 \%$ of it. A considerable portion of this deposit falls under the Nokrek BR, which lies in the southern and eastern sides of the buffer zone of the BR. Because of the ecological setting, peculiar land holding systems and lack of infrastructure, unscientific extraction of coal in unorganized sector is going on and the area affected by coal mining is increasing day-by-day.

Coal mining is restricted to the southern part of the BR between $200 \mathrm{~m}$ and $500 \mathrm{~m}$ elevation where the forest is tropical evergreen to semievergreen type. Commercial extraction of the coal started in 1985 in Darenggre area. Since then the number of coalmines in the BR has increased many folds. The activity is going on in eighteen villages. The thickness of the coal seam ranges from $0.46 \mathrm{~m}$ to $2.13 \mathrm{~m}$. Each of these villages has 50-300 quarries depending on the number of families in the village. Each quarry occupies an area within $30-50$ m radius, while 

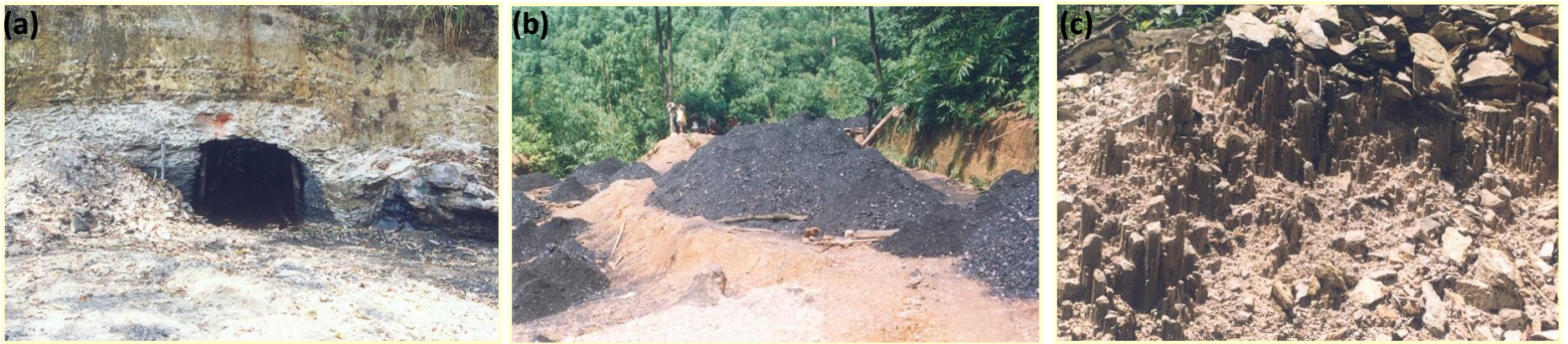

Fig. 2 | Coal mining in the study site. a: Rat-hole, b: Dumping of coal, c: Coal mine spoil.

the spoils around each quarry have a radius of 20-25 m. Tree felling in the coal mine areas has adversely affected the forest cover and mine spoils are devoid of herbaceous cover (Fig. $2 \mathrm{a}-\mathrm{c}$ ).

\section{Site selection}

Based on the field observations and vegetation characteristics, 4 sites - two in the core area i.e., undisturbed subtropical evergreen forest ( $C$ a and $\mathrm{C}-\mathrm{b}$ ) and two in coal mining areas (CM-a, $\mathrm{CM}-\mathrm{b}$ ) were selected for the study (Table. 1).

Table 1 | Selected study sites in the BR.

\begin{tabular}{l}
\multicolumn{1}{c}{ Type } \\
$\begin{array}{l}\text { Sites and their } \\
\text { altitudes }(\mathrm{m})\end{array}$ \\
$\begin{array}{l}\text { Undisturbed subtropical evergreen } \mathrm{C}-\mathrm{a}=1300, \mathrm{C}-\mathrm{b}=1300 \\
\text { forest }(\mathrm{C})\end{array}$ \\
$\begin{array}{l}\text { Coalmine spoils (CM) } \\
\text { CM- } \mathrm{a}=250, \mathrm{CM}-\mathrm{b}=314\end{array}$
\end{tabular}

\section{Soil sampling}

Soil samples were collected in January (winter) and August (rainy) for two consecutive years during 2001 - 2002 from the selected sites. At each site, three to five replicate samples were collected using a steel corer (6.3 cm diameter) from $0-10$ and $10-20 \mathrm{~cm}$ depths. The replicated samples were mixed thoroughly to obtain one composite sample. Fresh samples were used for the analysis of soil moisture content and the rest were air-dried and sieved through $2 \mathrm{~mm}$ sieve and stored for further analysis.

\section{Soil analysis}

Soil texture and bulk density were determined by Bouyoucos hydrometer method and gravimetric method respectively, ${ }^{4}$ and porosity was calculated from the bulk density data. Water-stable aggregate structure was determined by following Elliot's method ${ }^{5}$ and water holding capacity (WHC) was determined by Keen's box method. ${ }^{6}$ Soil moisture content was determined by taking $10 \mathrm{~g}$ fresh sieved soil, ${ }^{4}$ and $\mathrm{pH}$ was determined electrometrically in $1: 2.5 \mathrm{w} / \mathrm{v}$ suspension of soil in deionised water by a digital $\mathrm{pH}$ meter (SYSTRONICS-335)? Cation exchange capacity was determined after extracting the exchangeable bases from the soil with $1 \mathrm{M}$ ammonium acetate solution ( $\mathrm{pH}$ 7.0) followed by the replacement of ammonium- $\mathrm{N}$ with potassium chloride and distillation with magnesium oxide. ${ }^{4}$

Organic carbon was determined by colorimetric method.? Soil organic matter content was obtained by multiplying the soil organic carbon content by 1.724 assuming that the SOM contains $58 \%$ of carbon. ${ }^{4}$ Total Kjeldahl nitrogen was determined by digesting air-dried soil samples with concentrated sulphuric acid using Kjeltabs (Tector) as catalysts, on a block digester. Distillation and titration were done simultaneously in a Tector Kjeltec Auto 1030 Analyzer. Available phosphorus was determined after extracting soil phosphorus in $0.5 \mathrm{M}$ sodium bicarbonate solution by ammonium-molybdate blue method $^{4}$ and exchangeable potassium was determined by using flame photometer after extracting with $1 \mathrm{M}$ ammonium acetate solution $(\mathrm{pH}$ 7.0). ${ }^{4}$

\section{Statistical analysis}

The data were analyzed using two-way and three-way analysis of variance (ANOVA) (fixed 
effect model) to test the effects of season, soil depth and/or site on various physico-chemical properties of the soil. Inter-relationship between different soil properties, and effect of climatic variables on soil properties were analyzed by computing linear regression models and coefficients of correlation (r) according to Zar. ${ }^{8}$

\section{Results}

\section{Physical properties of soil}

Soil texture and bulk density (BD): The texture of the soil was sandy loam in the undisturbed core zone and sandy in the coalmine spoil. The clay content was generally higher at the lower depth $(10-20 \mathrm{~cm})$. Proportion of sand and silt were comparatively higher in the undisturbed core zone (Table 2). Two-way ANOVA revealed a significant variation $(P<0.01)$ in the proportion of fine particles (silt + clay) in soils of different sites. Bulk density of the soil showed a significant $(P<0.01)$ variation due to site and soil depth. At all sites the BD was lower in the upper layer $(0-10 \mathrm{~cm})$ compared to the lower layer $(10-$ $20 \mathrm{~cm}$ ) (Table 2).

Water holding capacity (WHC): Among the sites, WHC was comparatively higher in the core zone than the coalmine spoil, and it declined significantly $(P<0.01)$ from upper $(0-10 \mathrm{~cm})$ to lower $(10-20 \mathrm{~cm})$ soil depth (Fig. 3).

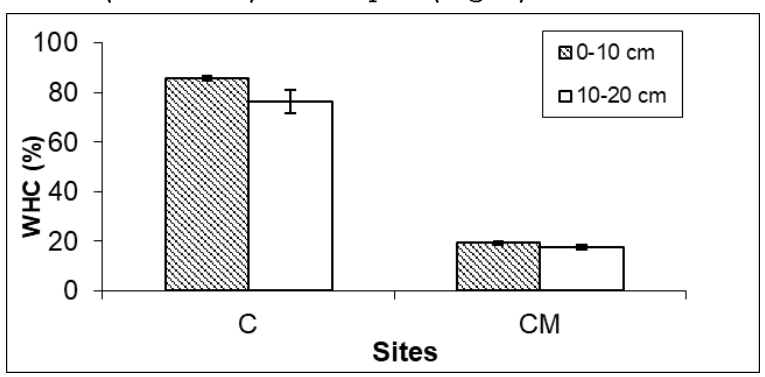

Fig. 3 | Mean water holding capacity (WHC \pm SE) of surface $(0-10 \mathrm{~cm})$ and subsurface $(10-20 \mathrm{~cm})$ soil layers of the BR \{core zone (C) and coalmine (CM) spoils\}. The values are means $( \pm \mathrm{SE})$ of 4 replicate sites.

Soil moisture content (SMC): Higher SMC was recorded in the undisturbed core zone compared to the mine spoils (Table 3). The SMC var- ied significantly $(P<0.01)$ between sites, seasons and soil depths. During rainy season, values were higher in the surface soil and lower in the subsurface soil layer whereas the trend was reversed during winter season at most sites (Table 3 \& Figure 4)

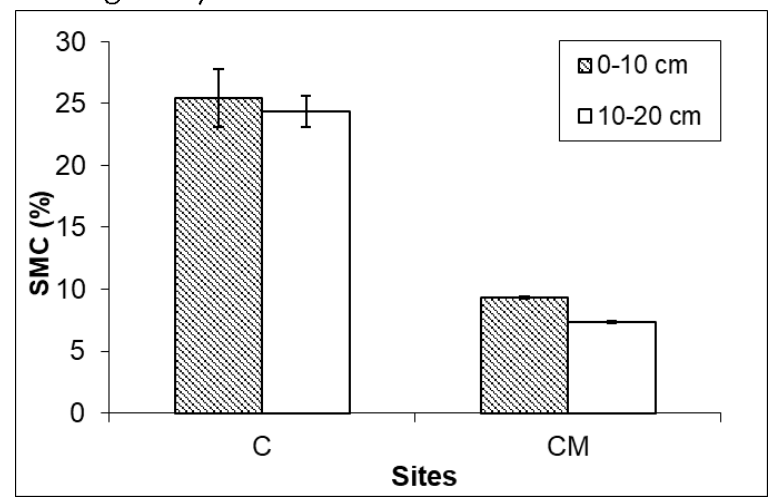

Fig. 4 | Mean soil moisture content $(S M C \pm S E)$ of surface $(0-10 \mathrm{~cm})$ and subsurface $(10-20 \mathrm{~cm})$ soil layers of the $\mathrm{BR}$ \{core zone $(\mathrm{C})$ and coalmine (CM) spoils\}. The values are means $( \pm S E)$ of seasonal values and 4 replicate sites.

Water-stable aggregates (WSA): Among different size classes of aggregates, the proportion of macroaggregates (0.3-2 $\mathrm{mm}$ ) was maximum in all the stands (Table 4$)$. The proportion of microaggregates $(<0.3 \mathrm{~mm})$ in soil was lesser than the macro-aggregates in the core zone. The coalmine spoil had more or less the same proportion of micro-aggregate and macro-aggregate (Figure 5). At all sites, the proportion of microaggregates was more in the upper soil layer than the lower layer.

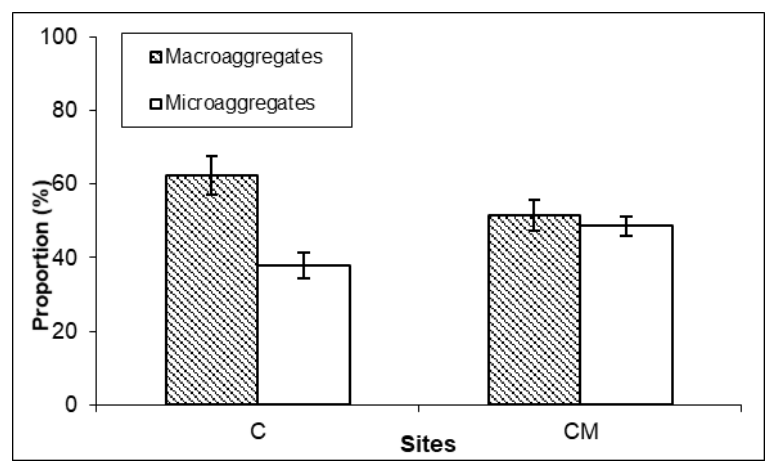

Fig. 5 | Water-stable aggregates $( \pm S E)$ in surface (0-10 $\mathrm{cm}$ ) soil layer of the BR \{core zone (C), and coalmine (CM) spoils\}. The values are means $( \pm S E)$ of 4 replicates. 
Table 2 | Texture and bulk density of soil at the study sites.

\begin{tabular}{|c|c|c|c|c|c|c|}
\hline \multirow[t]{2}{*}{ Sites } & \multirow[t]{2}{*}{ Depth $(\mathrm{cm})$} & \multicolumn{3}{|c|}{ Proportion of soil particles } & \multirow{2}{*}{$\begin{array}{c}\text { Textural } \\
\text { class }\end{array}$} & \multirow{2}{*}{$\begin{array}{c}\text { BD } \\
\left(\mathrm{g} / \mathrm{cm}^{3}\right)\end{array}$} \\
\hline & & Sand (\%) & Silt (\%) & Clay (\%) & & \\
\hline \multirow[t]{2}{*}{ Core zone* } & $0-10$ & 66.94 & 29.73 & 3.33 & SL & 1.20 \\
\hline & $10-20$ & 60.89 & 28.53 & 10.58 & SL & 1.79 \\
\hline \multirow{2}{*}{$\begin{array}{l}\text { Coal mine } \\
\text { spoil* }\end{array}$} & $0-10$ & 92.74 & 3.52 & 3.74 & $S$ & 1.70 \\
\hline & $10-20$ & 93.15 & 1.39 & 5.45 & S & 1.76 \\
\hline
\end{tabular}

$\mathrm{SL}=$ sandy loam; S=sandy; $\mathrm{BD}=$ bulk density;

*Mean of the replicate sites

Table 3 | Seasonal variation of soil moisture content $(\%, \pm S E)$ at the study sites.

\begin{tabular}{|c|c|c|c|c|c|c|c|}
\hline \multirow[t]{2}{*}{ Sites } & \multirow{2}{*}{$\begin{array}{l}\text { Depth } \\
\text { (cm) }\end{array}$} & \multicolumn{3}{|c|}{$1^{\text {st }}$ year } & \multicolumn{3}{|c|}{$2^{\text {nd }}$ year } \\
\hline & & Winter & Rainy & Mean & Winter & Rainy & Mean \\
\hline \multirow[t]{2}{*}{ Core zone* } & $0-10$ & $22.00 \pm 0.47$ & $29.13 \pm 0.79$ & 25.57 & $22.27 \pm 0.07$ & $33.27 \pm 0.83$ & 27.77 \\
\hline & $10-20$ & $25.15 \pm 0.30$ & $28.03 \pm 0.15$ & 26.59 & $22.53 \pm 0.15$ & $28.60 \pm 0.06$ & 25.57 \\
\hline \multirow{2}{*}{$\begin{array}{l}\text { Coal mine } \\
\text { spoil* }\end{array}$} & $0-10$ & $5.90 \pm 0.77$ & $12.83 \pm 0.20$ & 9.37 & $7.20 \pm 0.12$ & $11.23 \pm 0.12$ & 9.22 \\
\hline & $10-20$ & $5.90 \pm 0.77$ & $9.03 \pm 0.12$ & 7.47 & $4.63 \pm 0.03$ & $9.90 \pm 0.12$ & 7.27 \\
\hline
\end{tabular}

*Mean of the replicate sites

Table 4 | Weight distribution (\%) in different soil aggregate classes at different sites in the BR.

\begin{tabular}{|l|c|c|c|c|c|c|}
\hline & \multicolumn{7}{|c|}{ Septh $(\mathbf{c m})$} & \multicolumn{5}{c|}{ Soil aggregate class $(\mathbf{m m})$} \\
\hline & & $>\mathbf{4 . 7 5}$ & $\mathbf{2 - 4 . 7 5}$ & $\mathbf{0 . 3 - 2}$ & $\mathbf{0 . 0 6 3 - 0 . 3}$ & $<0.063$ \\
\hline Core zone* & $0-10$ & 11.15 & 16.29 & 34.79 & 22.47 & 15.32 \\
\hline \multirow{2}{*}{ Coal mine spoil* } & $10-20$ & 11.81 & 16.04 & 42.75 & 17.27 & 12.14 \\
\hline & $0-10$ & 7.86 & 5.00 & 38.60 & 38.77 & 10.69 \\
\hline & $10-20$ & 6.01 & 2.96 & 41.26 & 37.87 & 11.92 \\
\hline
\end{tabular}

Micro-aggregates $=<0.3 \mathrm{~mm}$; macro-aggregates $=>0.3 \mathrm{~mm}$;

*Mean of the replicate sites.

Table 5 | Seasonal variation of soil pH ( \pm SE). *Mean of the replicate sites

\begin{tabular}{|l|c|c|c|c|c|c|c|}
\hline Sites & $\begin{array}{c}\text { Depth } \\
(\mathbf{c m})\end{array}$ & Winter & Rainy & Mean & Winter & Rainy & Mean \\
\hline Core zone* & $0-10$ & $6.00 \pm 0.10$ & $5.91 \pm 0.01$ & 5.96 & $6.03 \pm 0.05$ & $5.29 \pm 0.02$ & 5.66 \\
\hline & $10-20$ & $5.88 \pm 0.02$ & $5.77 \pm 0.07$ & 5.83 & $5.93 \pm 0.01$ & $4.41 \pm 0.02$ & 5.17 \\
\hline Coal mine & $0-10$ & $3.50 \pm 0.04$ & $5.72 \pm 0.03$ & 4.61 & $4.89 \pm 0.03$ & $4.73 \pm 0.03$ & 4.81 \\
\hline spoil* & $10-20$ & $3.50 \pm 0.04$ & $5.74 \pm 0.003$ & 4.62 & $4.65 \pm 0.01$ & $4.39 \pm 0.06$ & 4.52 \\
\hline
\end{tabular}

*Mean of the replicate sites 
Table 6 | Seasonal variation of total soil organic carbon (\%, \pm SE) in soil. * Mean of the replicate sites

\begin{tabular}{|l|c|c|c|c|c|c|c|}
\hline Sites & $\begin{array}{c}\text { Depth } \\
(\mathbf{c m})\end{array}$ & Winter & $\begin{array}{c}\mathbf{1}^{\text {st }} \text { year } \\
\text { Rainy }\end{array}$ & Mean & Winter & Rainy & Mean \\
\hline Core & $0-10$ & $5.45 \pm 0.02$ & $6.70 \pm 0.04$ & 6.08 & $4.69 \pm 0.38$ & $6.86 \pm 0.07$ & 5.78 \\
\hline zone* & $10-20$ & $3.41 \pm 0.05$ & $5.53 \pm 0.05$ & 4.47 & $3.80 \pm 0.37$ & $5.39 \pm 0.02$ & 4.60 \\
\hline Coalmine & $0-10$ & $1.01 \pm 0.01$ & $2.37 \pm 0.01$ & 1.69 & $2.21 \pm 0.28$ & $0.39 \pm 0.03$ & 1.30 \\
\hline spoil* & $10-20$ & $1.01 \pm 0.01$ & $1.02 \pm 0.04$ & 1.02 & $2.11 \pm 0.31$ & $0.33 \pm 0.01$ & 1.22 \\
\hline
\end{tabular}

Table 7 | Seasonal variation of total nitrogen $(\%, \pm S E)$ in soil. *Mean of the replicate sites

\begin{tabular}{|l|c|c|c|c|c|c|c|}
\hline Sites & $\begin{array}{c}\text { Depth } \\
(\mathbf{c m})\end{array}$ & Winter & Rainy & Mean & Winter & Rainy & Mean \\
\hline Core & $0-10$ & $0.29 \pm 0.001$ & $0.35 \pm 0.000$ & 0.32 & $0.36 \pm 0.005$ & $0.34 \pm 0.003$ & 0.35 \\
\hline zone* & $10-20$ & $0.22 \pm 0.000$ & $0.28 \pm 0.003$ & 0.25 & $0.31 \pm 0.005$ & $0.27 \pm 0.003$ & 0.29 \\
\hline $\begin{array}{l}\text { Coalmine } \\
\text { spoil* }\end{array}$ & $0-10$ & $0.03 \pm 0.001$ & $0.02 \pm 0.000$ & 0.03 & $.0004 \pm 0.001$ & $0.09 \pm 0.002$ & 0.05 \\
\hline & $10-20$ & $0.03 \pm 0.001$ & $0.05 \pm 0.0003$ & 0.04 & $0.004 \pm 0.001$ & $0.10 \pm 0.001$ & 0.05 \\
\hline
\end{tabular}

Table 8 | Seasonal variation of available phosphorus $\left(\mu \mathrm{g} \mathrm{g}^{-1}, \pm \mathrm{SE}\right)$ in soil. * Mean of the replicate sites

\begin{tabular}{|l|c|c|c|c|c|c|c|}
\hline Sites & $\begin{array}{c}\text { Depth } \\
(\mathbf{c m})\end{array}$ & Winter & Rainy & Mean & Winter & Rainy & Mean \\
\hline \multirow{2}{*}{ Core zone* } & $0-10$ & $5.19 \pm 0.03$ & $3.19 \pm 0.04$ & 4.19 & $5.02 \pm 0.00$ & $4.10 \pm 0.17$ & 4.56 \\
\hline & $10-20$ & $4.01 \pm 0.06$ & $2.61 \pm 0.07$ & 3.31 & $3.57 \pm 0.03$ & $3.17 \pm 0.03$ & 3.37 \\
\hline \multirow{2}{*}{$\begin{array}{l}\text { Coal } \\
\text { mine spoil* }\end{array}$} & $0-10$ & $1.46 \pm 0.03$ & $1.73 \pm 0.00$ & 1.60 & $1.56 \pm 0.03$ & $0.90 \pm 0.00$ & 1.23 \\
\hline & $10-20$ & $1.46 \pm 0.03$ & $3.16 \pm 0.00$ & 2.31 & $1.91 \pm 0.03$ & $0.80 \pm 0.00$ & 1.36 \\
\hline
\end{tabular}

Table 9 | Seasonal variation in exchangeable potassium $\left(\mu \mathrm{g} \mathrm{g}^{-1}, \pm \mathrm{SE}\right)$ in soils at the study sites. * Mean of the replicate sites

\begin{tabular}{|l|c|c|c|c|c|c|c|}
\hline Sites & $\begin{array}{c}\text { Depth } \\
(\mathbf{c m})\end{array}$ & Winter & Rainy & Mean & Winter & Rainy & Mean \\
\hline Core zone* & $0-10$ & $310 \pm 3$ & $220 \pm 7$ & 265 & $200 \pm 3$ & $260 \pm 4$ & 230 \\
\hline & $10-20$ & $220 \pm 3$ & $190 \pm 3$ & 205 & $150 \pm 3$ & $180 \pm 2$ & 165 \\
\hline $\begin{array}{l}\text { Coalmine } \\
\text { spoil* }\end{array}$ & $0-10$ & $80 \pm 3$ & $70 \pm 3$ & 75 & $50 \pm 4$ & $40 \pm 2$ & 45 \\
\hline
\end{tabular}

Table 10 | Total soil organic carbon, total nitrogen contents and $\mathrm{C} / \mathrm{N}$ ratio in macro (MaA)- and micro (MiA)aggregates in soils of the BR.

\begin{tabular}{|c|c|c|c|c|c|c|c|}
\hline \multirow[t]{2}{*}{ Sites } & \multirow[t]{2}{*}{ Depth $(\mathrm{cm})$} & \multicolumn{2}{|c|}{ SOC } & \multicolumn{2}{|c|}{ TN } & \multicolumn{2}{|c|}{$C / N$} \\
\hline & & MaA & MiA & MaA & MiA & MaA & MiA \\
\hline \multirow[t]{2}{*}{ Core zone } & $0-10$ & 3.06 & 4.11 & 0.42 & 0.41 & 7.24 & 9.96 \\
\hline & $10-20$ & 2.25 & 3.47 & 0.36 & 0.31 & 6.25 & 11.37 \\
\hline \multirow[t]{2}{*}{ Coal mine spoils } & $0-10$ & 0.38 & 0.30 & 0.07 & 0.09 & 5.61 & 1.67 \\
\hline & $10-20$ & 0.23 & 0.34 & 0.07 & 0.08 & 3.15 & 4.28 \\
\hline
\end{tabular}




\section{Chemical properties of soil}

Soil pH: The soil was acidic $(\mathrm{pH}$ ranges from $3.50-6.14)$ at all sites. The acidity increased significantly $(P<0.01)$ with the increase in soil depth and varied between different seasons; the values were generally high during winter and low during rainy season (Table 5 \& Figure 6). Lowest $\mathrm{pH}$ (3.50) was recorded in the coalmine spoil during winter season in both the soil depth.

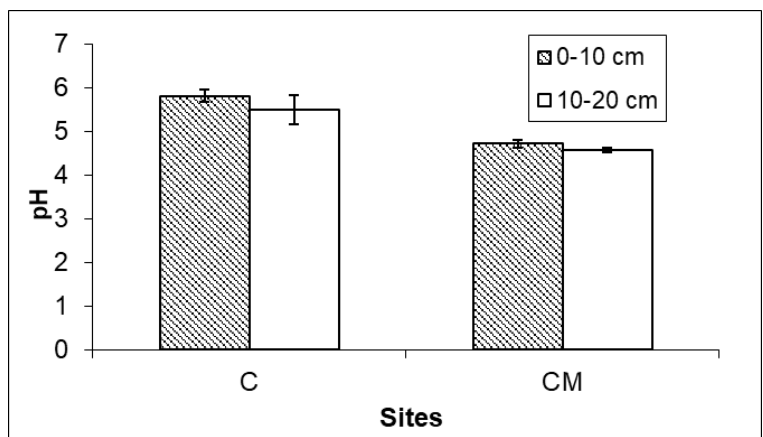

Fig. 6 | Soil pH $( \pm S E)$ of surface $(0-10 \mathrm{~cm})$ and subsurface $(10-20 \mathrm{~cm})$ soil layers at different sites of the BR \{core zone $(\mathrm{C})$ and coalmine (CM) spoils\}. The values are means $( \pm \mathrm{SE})$ of seasonal values and 4 replicate sites.

Cation exchange capacity (CEC): Two-way ANOVA revealed a significant variation $(P<0.01)$ in CEC between different sites. The minimum value (2.92 meq/100g) was recorded in the coalmine spoil. The upper layer had significantly higher $(P<0.01)$ CEC than the lower layer (Fig. 7) in the core zone but lower CEC in the coal mine zone.

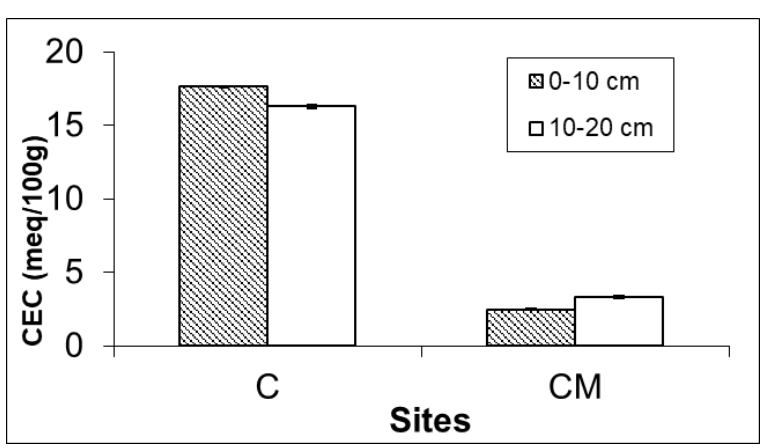

Fig. 7 | Cation exchange capacity (CEC, \pm SE) of surface $(0-10 \mathrm{~cm})$ and subsurface $(10-20 \mathrm{~cm})$ soil layers of the $\mathrm{BR}$ \{core zone $(\mathrm{C})$ and coalmine $(\mathrm{CM})$ spoils\}. The values are means $( \pm S E)$ of 4 replicate sites.
Total soil organic carbon (SOC): The SOC content was minimum during the winter season and maximum during the rainy season, and it declined significantly $(P<0.01)$ with the increase in soil depth. The maximum value $(6.86 \%)$ was obtained in the core zone during rainy season at $0-10 \mathrm{~cm}$ depth and minimum value $(0.33 \%)$ was recorded in the mine spoils during rainy season at $10-20 \mathrm{~cm}$ depth (Table 6 \& Fig. 8). Three-way ANOVA revealed significant variation $(P<0.01)$ in SOC content between sites and seasons.

Total nitrogen (TN): TN content showed a

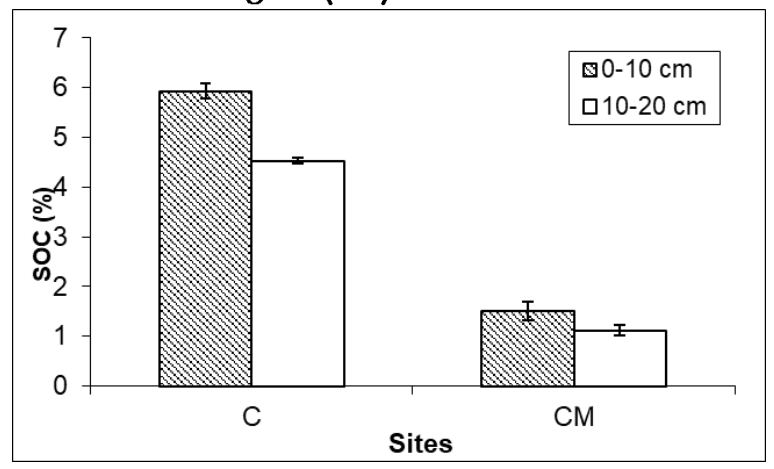

Fig. 8 | Mean soil organic carbon $(S O C \pm S E)$ of surface (0 $-10 \mathrm{~cm})$ and subsurface $(10-20 \mathrm{~cm})$ soil layers of the BR \{core zone $(\mathrm{C})$, and coalmine $(\mathrm{CM})$ spoils\}. The values are means $( \pm \mathrm{SE})$ of seasonal values and 4 replicate sites.

significant $(P<0.01)$ variation between stands, year, season and soil depth. The concentration was minimum during winter season and maximum during rainy season, declining significantly $(P<0.01)$ with the increase in soil depth. Core zone had the highest record of TN $(0.36 \%)$ and coal mine spoil recorded the lowest value (0.0004\%) (Table 7 \& Fig. 9).

Available phosphorus (P): Available $P$ showed a significant $(P<0.01)$ variation between stands and seasons. In the core zone, the maxima were recorded during winter and minima during the rainy season at core zone. At mining sites, a reverse trend was observed. The soil in the core zone had maximum concentration of available phosphorus (5.19 $\mu \mathrm{g} \mathrm{g}^{-1}$ ) while that of the mine spoils had the minimum concentration $\left(0.80 \mu \mathrm{g} \mathrm{g}^{-1}\right)$. The concentration also declined with the increase in soil depth (Table 8 \& Figure 10). 


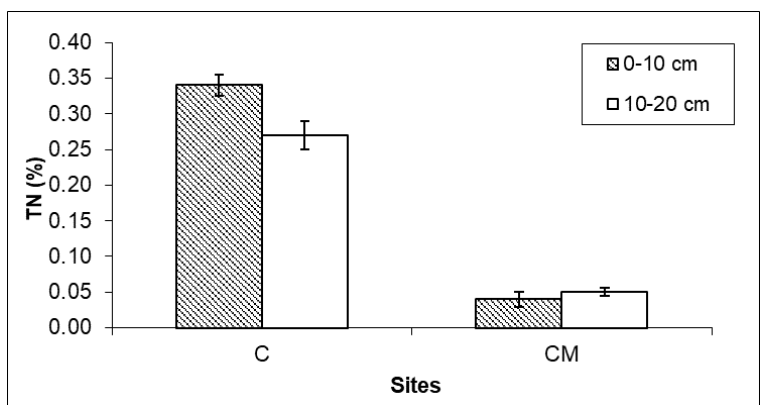

Fig. 9 | Mean total nitrogen (TN, \pm SE) of surface (0-10 $\mathrm{cm})$ and subsurface $(10-20 \mathrm{~cm})$ soil layers of the BR \{core zone (C), and coalmine (CM) spoils\}. The values are means $( \pm S E)$ of seasonal values and 4 replicate sites.

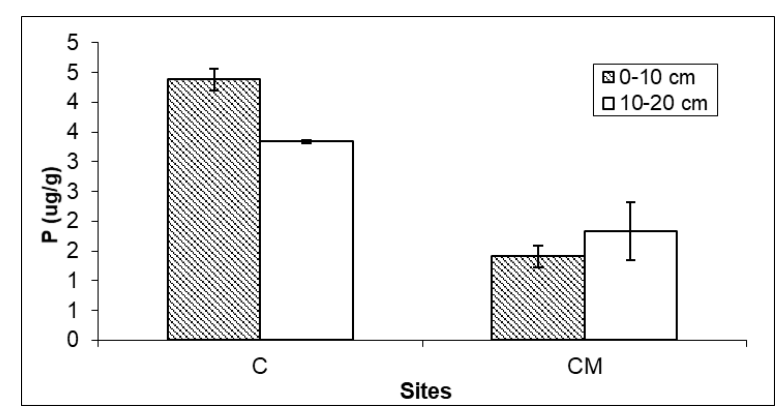

Fig. 10 | Mean available phosphorus content $(P, \pm S E)$ of surface $(0-10 \mathrm{~cm})$ and subsurface $(10-20 \mathrm{~cm})$ soil layers of the BR \{core zone (C) and coalmine (CM) spoils\}. The values are means $( \pm S E)$ of seasonal values and 4 replicate sites.

Exchangeable potassium (K): The core zone had the higher concentration of exchangeable $\mathrm{K}$ $\left(265 \mu \mathrm{g} \mathrm{g}^{-1}\right)$ than the coalmine spoils $\left(45 \mu \mathrm{g} \mathrm{g}^{-1}\right)$ (Table 9 \& Figure 11). At all sites, concentration was significantly $(P<0.01)$ higher in the surface soil layer than the subsurface layer. It was minimum during rainy season and maximum during the winter season.

Carbon, nitrogen and $\mathrm{C} / \mathrm{N}$ ratio in waterstable aggregates: Organic carbon content in the micro-aggregate was found to be higher than the macro-aggregate structure in most of the cases (Table 10). Highest $C$ and $N$ concentrations in both micro- and macro-aggregates, were recorded the undisturbed core zone and decreasing in mine spoils. $\mathrm{C} / \mathrm{N}$ ratio was greater in the micro-aggregates than the macro-aggregates in the undisturbed core zone. This trend was reversed in case of coalmine spoil (Table 10).

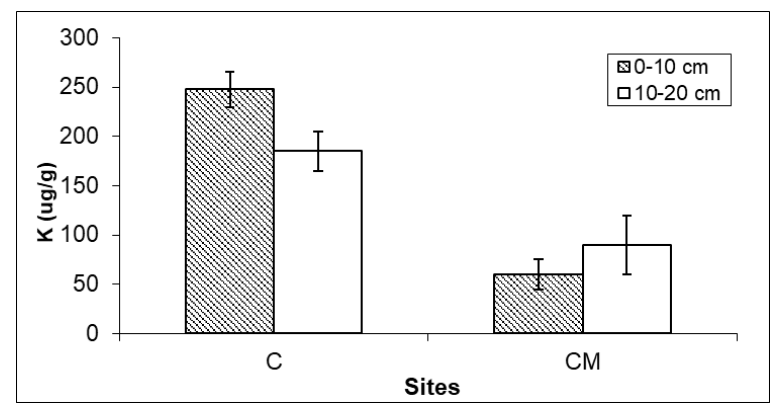

Fig. 11 | Mean exchangeable potassium $(\mathrm{K}, \pm \mathrm{SE})$ of surface $(0-10 \mathrm{~cm})$ and subsurface $(10-20 \mathrm{~cm})$ soil layers of the $B R$ \{core zone $(\mathrm{C})$ and coalmine (CM) spoils\}. The values are means $( \pm S E)$ of seasonal values and 4 replicate sites.

\section{Discussion}

The physico-chemical properties of mine spoils were different from those of core zone of the BR. The effect of these activities started with the removal of vegetal cover and dumping of the mine spoil on top of the natural soil. The bulk density registered a marked increase in the surface soil at coal mining sites. This is attributed to a significant decrease in silt particles as well as organic matter content. Similar finding, loss of finer soil particles, especially the clay component from the soil after disturbance has been reported by Eyre. ${ }^{9}$ Bulk density of mine spoils is comparatively higher as compared to the native soil which is in accordance with the findings of Sadhu et al. ${ }^{10}$ High bulk density would pose restriction to the growth of deeper rooted plants and may be one of the reasons of cessation of plant growth. ${ }^{11}$

Similarly decline in WHC from the core zone compared to coal mining sites is attributed to increase in the proportion of sand particles and decrease in organic matter content which is in accordance with the trend observed by Bahrami et al. ${ }^{1}$ The soils of mining sites were almost without any vegetal cover, coarse textured with low SOM content, therefore had very low SMC. Higher evaporation from the soil in the absence of tree cover and low water retention due to higher proportion of sand were the reasons for low SMC of mine spoils. 
The percentage of macro-aggregates in the coal mine spoil was significantly lower $(P<0.01)$ than the undisturbed core zone. This has a strong influence on $\mathrm{pH}$ and CEC as is evident from positive relationships between macroaggregates and $\mathrm{pH}$ and CEC. Aggregate structure breaks down as successive layers of soil are removed and stockpiled elsewhere on the site when mining begins. The resulting compaction reduces water holding capacity and aeration. ${ }^{12}$

The coalmine spoil was highly acidic primarily due to the oxidation of iron pyrites in the overburden. ${ }^{13}$ These minerals, when exposed to air and moisture, oxidize to produce acid and soluble salts. Lowering of $\mathrm{pH}$ on one hand strongly hampers the availability of a number of essential nutrients in the soil, ${ }^{14}$ and on the other increases the availability of iron, aluminium and manganese to plant. ${ }^{15}$ Therefore under very acidic condition these elements become toxic to plants. Low concentrations of cations cause acidity as $\mathrm{Ca}^{2+}, \mathrm{Mg}^{2+}, \mathrm{K}^{+}$, and $\mathrm{Na}^{+}$are leached down the soil profile by excess rains. ${ }^{16}$

The mine spoils are poor in organic carbon, $\mathrm{TN}$, available $\mathrm{P}$ and exchangeable $\mathrm{K}$. Sadhu et al. ${ }^{17}$ also reported low percentage of nutrients in coalmine spoil compared to the native soil. The shortage of organic matter is attributed to the absence of litter. ${ }^{18}$ Lower organic carbon content in spoil than their respective native soil is attributable to lack of humus content. In contrast, Toy and Shay ${ }^{19}$ did not get significant difference in organic matter content between the mine spoils and natural soils in Northern Great Plains.

Low $\mathrm{N}$ and $\mathrm{P}$ in the mine spoils has been attributed to leaching and lack of binding power of phosphorus. ${ }^{12}$ Ralte et al. ${ }^{20}$ observed significant reduction in the soil fertility due to different land-use practices as compared to the undisturbed forest. This was mainly due to significant reduction in the microbial biomass and enzyme activities as the coalmine spoils were devoid of vegetal cover and microbial activities were thus reduced. Lunt and Hedger ${ }^{21}$ also reported lack of macronutrients in the mine wastes where phosphorus is a limiting factor during early succession and colonization.

\section{References}

I. Bahrami A, Emadodin I, Atashi MR \& Bork HR (20I0), Land-use change and soil degradation: A case study, North of Iran. Agriculture and Biology Journal of North America I(4), 600-605.

2. Maharana JK \& Patel AK (20I3). Physico-chemical characterization and mine soil genesis in age series coal mine overburden spoil chronosequence in a dry tropical environment. Phylogenetics E Evolutionary Biology $\mathrm{I}(\mathrm{I}), \mathrm{I}-7$.

3. Barnhisel RI \& Hower JM (1997). Coal surface mine reclamation in the eastern United States: The revegetation of disturbed lands to hayland/ pastureland or cropland. In: Advances in Agronomy (D.L. Sparks Ed.), pp. 233-237, Academic Press, New York.

4. Allen SC, Grimshaw HM, Parkinson JA \& Quarmby C (1974). Chemical Analysis of Ecological Materials. Blackwell Scientific Publications, Oxford, England.

5. Elliott ET (1986). Aggregate structure and carbon, nitrogen and phosphorus in native and cultivated soils. Soil Science Society of American Journal so, 627-633.

6. Piper CS (1942). Soil and Plant Analysis. Hans Publishers, Bombay, India

7. Anderson JM \& Ingram JSI (1993). Tropical Soil Biology and Fertility - A Handbook of Methods, $2^{\text {nd }}$ ed., C.A.B. International, Wallingford, UK.

8. Zar JH (1974). Biostatistical Analysis, $2^{\text {nd }}$ edn. Prentice Hall, Englewood Cliffs, New Jersey, USA

9. Eyre SR (1968). Vegetation and Soils - AWorld Picture. Edward Arnold Publishers Ltd., U.K.

Io. Sadhu K, Adhikari K \& Gangopadhyay A (20I2). Effect of mine spoil on native soil of lower Gondhwana coal fields: Raniganj coal mine areas, India. International Journal of Environmental Sciences 2(3), 1675-1687.

II. Ghose MK (2004). Effect of opencast mining on soil fertility. Journal of Environment and Industrial Research, 63, 1006-1009.

I2. Sheoran V, Sheoran AS \& Poonia P (2010). Soil reclamation of abandoned mine land by revegetation: A Review. International Journal of Soil, Sediment and Water 3, $\mathrm{I}-2 \mathrm{O}$.

I3. Singh AN, Raghubanshi AS \& Singh JS (2002). Plantations as a tool for mine spoil restoration. Current Science 82, I436-I44I.

I4. Hossner LR, Shahandeh H \& Birkhead JA (1997). The impact of acid forming materials on plant growth on reclaimed mine soil. Journal of Soil and Water Conservation 52, II8-I25. 
I5. Iverson LK \& Wali MK (1992). Grassland rehabilitation after coal and mineral extraction in the Western United States and Canada. In: Ecosystem Rebabilitation (M.K. Wali Ed.), Vol. 2, pp. 85-I29, Ecosystem Analysis and Synthesis, SPB Academic Publishing Co., The Hague, The Netherlands.

16. Mani PK (2014). Problems soils and soil acidity. https:// www.slideshare.net (January 8, 2014)

17. Sadhu K, Adhikari K \& Gangopadhyay A. (20I2). Effect of mine spoil on native soil of Lower Gondwana coal fields: Raniganj coal mines areas, India. International Journal of Environmental Sciences 2(3), 1675-1687

18. Schafer WM, Nielsenand GA \& Nettleton WD (1980). Mine spoil genesis and morphology I a spoil chronology in Montana. Soil Science Society of American Journal $44,802-807$.
19. Toy SJ \& Shay D (1987). Comparison of some soil properties on natural and reclaimed hill slopes. Soil Science I43, 264-277.

2o. Ralte V, Pandey HN, Barik SK \& Prabhu S. (2005). Changes in Microbial Biomass and Activity in Relation to Shifting Cultivation and Horticultural Practices in Subtropical Evergreen Forest Ecosystem of North-East India. Acta Oecologia 28, 163-I72.

2I. Lunt PH \& Hedger JN (2003). Effects of organic enrichment of mine spoil on growth and nutrient uptake in oak seedlings inoculated with selected ectomycorrhizal fungi. Restoration Ecology II, 125-130. 